\title{
ANALISIS KESENJANGAN PRODUKTIVITAS PADI DI JAWA DAN LUAR JAWA
}

\author{
(Wetland Paddy Yield Gap Analysis in Java and Outside of Java) \\ Ratna Rizki Amalia ${ }^{1}$, Octavia Rizky Prasetyo ${ }^{2}$, Kadir ${ }^{3}$ \\ Badan Pusat Statistik ${ }^{1,2,3}$ \\ Jl. Dr. Sutomo 6-8, Jakarta \\ E-mail: ratna.amalia@bps.go.id
}

\begin{abstract}
ABSTRAK
Penelitian ini bertujuan untuk menganalisis kesenjangan produktivitas padi sawah antara Jawa dan luar jawa serta mengidentifikasi variabel-variabel yang berkontribusi dalam menjelaskan kesenjangan tersebut. Data yang digunakan adalah hasil Survei Ubinan 2018 yang dikumpulkan oleh BPS. Data dianalisis menggunakan model regresi Ordinary Least Square (OLS) dengan menerapkan robust standard error untuk mengatasi isu heteroskedastisitas. Tanpa mengentrol variabel lain yang mempengaruhi produktivitas, hasil estimasi menunjukkan bahwa produktivitas padi sawah di wilayah luar Jawa sekitar 30 persen lebih rendah daripadi produktivitas padi sawah di Jawa. Hal ini mengindikasikan bahwa potensi peningkatan produktivitas di luar Jawa masih cukup besar. Analisis lebih lanjut dengan menerapkan teknik dekomposisi Blinder-Oaxaca menunjukkan bahwa hanya sekitar 16 persen dari total perbedaan tersebut yang dapat terjelaskan oleh perbedaan karakteristik antara kedua wilayah, seperti akses terhadap irigasi, penggunaan pupuk, penerapan teknik budidaya jajar legowo, dan partisipasi dalam keanggotaan kelompok tani. Hasil dekomposisi juga memperlihatkan bahwa ketimpangan produktivitas antar keduanya dapat dipersempit dengan meningkatkan akses terhadap irigasi dan penggunaan pupuk di luar Jawa.
\end{abstract}

Kata kunci: regresi OLS, dekomposisi Blinder-Oaxaca, produktivitas, padi

\begin{abstract}
This study aims to analyze the regional wetland paddy productivity gap between Jawa dan outside Jawa regions as well as identify variables that could explain the gap. Data used are the results of the 2018 Crop Cutting Survey collected by Statistics Indonesia (BPS). The data were analyzed using OLS regression model with robust standard errors to address the issue of heteroscedasticity. Without controlling other variables affecting productivity, our estimation shows that the wetland paddy productivity of outside Jawa was about 30 per cent lower than Jawa. The finding indicates that there is still a vast potential for yield outside Jawa to be increased. Further analysis by implementing Blinder-Oaxaca decomposition technique shows that the difference can explain only 16 per cent of the total gap in characteristics between the two regions, such as access to irrigation, fertilizer use, implementation of "Jajar Legowo" cultivation technique, and farmer group membership. The decomposition results also pointed out that the gap in productivity between the two could be narrowed by improving access to irrigation and fertilizer use in outside Jawa.
\end{abstract}

Keywords: OLS regression, Blinder-Oaxaca decomposition, yield, wetland paddy

\section{PENDAHULUAN}

Meskipun merupakan penghasil beras terbesar ketiga di dunia, Indonesia masih dihadapkan pada persoalan pangan. Hampir setiap tahun Indonesia masih harus mengimpor beras, terutama dari Thailand dan Vietnam untuk dapat menjaga cadangan beras nasional (Indonesia Investment, 2017). Badan Pusat Statistik (BPS) mencatat, pemerintah Indonesia telah mengimpor beras sebanyak 2,25 juta ton dengan nilai US\$ 1,04 milyar sepanjang tahun 2018 (BPS, 2019). Pertumbuhan populasi yang diikuti dengan peningkatan permintaan konsumsi beras menjadi tantangan serius bagi penentuan kebijakan pangan di Indonesia. Berdasarkan data BPS (2017), konsumsi beras di Indonesia mencapai 111,58 kilogram per kapita per tahun. Meskipun tren 
konsumsi beras menunjukkan penurunan dari tahun ke tahun karena adanya pergeseran konsumsi beras sebagai makanan pokok ke pengganti beras dan makanan jadi, angka tersebut masih cukup tinggi.

Peningkatan produksi padi merupakan salah satu solusi untuk menangani permasalahan ketahanan pangan nasional. Hal ini dapat dilakukan dengan cara meningkatkan produktivitas atau dengan memperluas areal tanam. Namun, mengingat tingginya konversi lahan sawah menjadi lahan non sawah, peningkatan produktivitas merupakan solusi yang lebih menjanjikan dalam meningkatkan produksi. Terkait hal ini, isu yang sangat penting untuk menjadi fokus perhatian terkait upaya peningkatan produksi adalah kesenjangan produktivitas padi yang terjadi antara Jawa dan Luar Jawa. Pada 2015, produktivitas padi di Jawa mencapai 6,1 juta ton gabah kering giling (GKG) per hektar jauh lebih tinggi dibanding Luar Jawa yang hanya mencapai 4,7 juta ton GKG per hektar. Hal ini mengindikasikan bahwa potensi peningkatan produksi padi nasional masih sangat besar melalui peningkatan produktivitas di Luar Jawa. Jika gap produktivitas antara keduanya dapat dipersempit, hal ini dapat berkontribusi terhadap peningkatan produksi beras nasional secara signifikan.

Studi ini bertujuan untuk menganalisis kesenjangan (gap) produktivitas padi sawah yang terjadi antara Jawa dan luar Jawa serta mengidentifikasi variabel-variabel yang berkontribusi dalam menjelaskan kesenjangan produktivitas tersebut. Penelitian ini diharapkan dapat memberi masukan terhadap upaya untuk mempersempit kesenjangan yang ada dengan memacu peningkatan produktivitas padi di luar Jawa.

\section{METODE}

Data yang digunakan dalam penelitian ini merupakan data hasil Survei Ubinan tahun 2018 yang dilaksanakan oleh BPS. Survei Ubinan Tanaman Pangan merupakan survei rutin yang dilakukan BPS setiap tahun dalam tiga periode, yaitu subround/SR I (periode Januari-April), SR II (periode MeiAgustus), dan SR III (periode September-Desember) (BPS, 2018). Tujuan utama pelaksanaan Survei Ubinan adalah untuk memperoleh informasi mengenai produktivitas tanaman pangan (padi dan palawija) melalui pengukuran hasil panen pada sampel plot berukuran $6,25 \mathrm{~m}^{2}$ yang kemudian diekstrapolasi menjadi angka produktivitas dalam ton per hektar. Selain data produktivitas, Survei Ubinan juga menghasilkan informasi pendukung lainnya, antara lain koordinat lokasi ubinan, jenis lahan, cara penanaman, sistem penanaman jajar legowo (khusus padi), jenis kegiatan peningkatan produksi, banyaknya benih yang digunakan, jenis varietas benih yang digunakan (khusus padi dan jagung), banyaknya pupuk yang digunakan, informasi cara pengendalian serangan hama/OPT, informasi bantuan benih, pupuk, alsintan, dan informasi kualitatif terkait dengan produktivitas. Survei Ubinan menggunakan pendekatan rumah tangga. Oleh karena itu, unit observasi dalam penelitian ini adalah rumah tangga. Dengan kata lain, kesenjangan produktivitas yang dimaksud dalam penelitian ini adalah kesenjangan produktivitas padi antara rumah tangga petani padi di Jawa dan luar Jawa.

Penelitian ini hanya berfokus pada produktivitas padi sawah yang merupakan penyumbang hampir 94 persen dari total produksi padi nasional. Jumlah sampel dalam penelitian ini sebanyak 63.071 rumah tangga usaha tanaman padi sawah. Analisis pada penelitian ini tidak hanya dibatasi pada pengaruh wilayah (Jawa dan Luar Jawa) terhadap produktivitas. Untuk memperkaya analisis, penelitian ini juga menelaah hubungan antara produktivitas padi sawah dengan variabel-variabel lain yang berpengaruh terhadap produktivitas, yang dapat menjelaskan kesenjangan produktivitas antara kedua wilayah. Dalam penelitian wilayah Jawa mencakup semua provinsi di Jawa (Jawa Barat, DKI Jakarta, Banten, Jawa Tengah, dan Jawa Timur) sementara wilayah luar Jawa mencakup semua provinsi selain provinsi tersebut di luar Jawa.

\section{Estimasi kesenjangan produktivitas}

Untuk menganalisis pengaruh variabel perbedaan wilayah (Jawa dan luar Jawa) serta variabelvariabel lainnya terhadap produktivitas, kami menggunakan model regresi Ordinary Least Square (OLS). Regresi OLS adalah metode ekonometrik yang memperkirakan hubungan antara satu variabel dependen dengan satu atau lebih variabel independen yang dinyatakan dalam satu persamaan linier. Metode ini mengestimasi hubungan dengan meminimalkan jumlah kesalahan (error) kuadrat. Salah 
satu asumsi krusial dalam estimasi koefisien regresi dengan OLS agar hasil estimasi memiliki minimum standard error adalah residual memiliki varians konstan (homoskedastis). Sayangnya, dalam banyak kasus, khususnya ketika kita menganalisis data cross-section, kondisi ini serangkali tidak terpenuhi, yaitu residual justru memiliki varians yang berbeda untuk setiap observasi (heteroskedastis). Oleh karena itu, untuk mengatasi pengaruh heteroskedastisitas tersebut kami menggunakan model regresi OLS dengan robust standard errors. Perhitungan standard errors diklusterkan (Nichols dan Schaffer, 2007) pada level kecamatan.

Model regresi yang digunakan di dalam penelitian ini adalah sebagai berikut:

$$
\ln y_{i}=x_{i}^{\prime} \beta_{i}+\delta \text { Luar Jawa }{ }_{i}+\varepsilon_{i}
$$

Di mana $\ln y_{i}$ adalah logaritma natural produktivitas padi sawah rumah tangga ke- $i$ dan $x_{i}$ adalah matrix covariate dari faktor-faktor yang mempengaruhi produktivitas rumah tangga padi sawah ke- $i$ (jenis lahan, cara penanaman, penggunaan pupuuk, jenis varietas, penggunaan pestisida, penerapan jajar legowo, bantuan pemerintah, keanggotaan kelompok tani, periode panen). Penjelasan rinci mengenai semua variabel yang diikutsertakan ke dalam model dapat dilihat pada Tabel 1. Komponen error $\varepsilon_{i}$ diasumsikan independent and identically distributed (i.i.d). Untuk mengantisipasi asumsi ini terlanggar kami menggunakan robust standard errors untuk mengoreksi efek hetoreskedastisitas. Untuk mengestimasi gap produktivitas antar wilayah, kami mengikutsertakan variabel boneka Luar Jawa $_{i}$, yang bernilai 1 untuk rumah tangga di luar Jawa dan 0 sebaliknya. Dengan demikian, fokus utama penelitian kami adalah untuk mengestimasi koefisien $\delta$ yang menjelaskan rata-rata ketimpangan produktivitas padi sawah antar wilayah (Jawa dan luar Jawa). Interpretasi ini memungkinkan karena bentuk fungsional (fungsional form) dari model yang digunakan adalah semi-log. Idealnya, perhitungan rata-rata gap dikoreksi dengan formula berikut $\left(e^{\delta}-1\right) \times 100 \%$ (Hill et.al, 2011).

Pertama-tama, persamaan (1) diestimasi dengan hanya memasukkan variabel wilayah sebagai variabel independen sehingga dapat diketahui besarnya rata-rata ketimpangan produktivitas padi sawah antar wilayah tanpa mengontrol pengaruh variabel-variabel lain pada Tabel 1, yang juga mempengaruhi produktivitas padi sawah. Pada tahap kedua, kami memasukkan variabel-variabel lain ke dalam model sehingga dapat diketahui pengaruh dari variabel-variabel penjelas lainnya terhadap produktivitas padi sawah. Kami juga mengestimasi persamaan regresi secara terpisah untuk masing-masing wilayah.

Tabel 1. Definisi variabel bebas dan variable terikat

Variabel terikat: logaritma dari produktivitas padi sawah; produktivitas padi sawah menggunakan satuan ton per hektar

Variabel bebas:

Luar jawa

Jenis lahan

Cara penanaman

Penggunaan

benih

Pupuk

Pestisida

Jarwo
Jika luar jawa maka berkode 1 , sementara jika Jawa maka berkode 0 Jika jenis lahan merupakan sawah irigasi maka berkode 1 , sementara jenis lahan lainya (sawah tadah hujan, sawah rawa pasang surut, sawah rawa lebak dan bukan sawah) berkode 0

Jika cara penanaman menggunakan sistem monokultur maka berkode 1 , jika campuran/tumpangsari maka berkode 0

Jika menggunakan benih hibrida maka berkode 1 , jika lainnya berkode 0

Berkode 1 jika budidaya tanaman padi sawah menggunakan pupuk, berkode 0 jika tidak menggunakan pupuk.

Berkode 1 jika menggunakan pestisida untuk pengendalian hama dan organisme pengganggu tumbuhan, berkode 0 jika tidak menggunakan.

Penerapan pola tanam jajar legowo (jarwo) ini dibagi ke dalam 5 kategori yaitu tidak menggunakan sistem jarwo (sebagai referensi), jarwo 2:1, Jarwo 4:1, Jarwo 6:1, dan Jarwo lainnya 
Variabel terikat: logaritma dari produktivitas padi sawah; produktivitas padi sawah menggunakan satuan ton per hektar

\section{Bantuan pemerintah \\ Poktan}

Periode panen
Jika mendapat bantuan pemerintah berkode 1 , tidak mendapat bantuan pemerintah berkode 0

Jika petani menjadi anggota kelompok tani maka berkode 1 , jika tidak berkode 0

Periode panen dibagi ke dalam 3 periode yang disebut subround (per 4 bulan) yaitu subround I (Januari-April) sebagai referensi, subround 2 (Mei-Agustus), dan subround $\mathbf{3}$ (September-Desember)

\section{Dekomposisi kesenjangan produktivitas}

Kami meyakini bahwa kesanjangan produktivitas antara Jawa dan luar Jawa disebabkan oleh perbedaan karakteristik budidaya antar kedua wilayah, karakteristik petani (Survei Ubinan tidak menangkap hal ini), dan faktor-faktor lain yang tidak terjelaskan (terkait kondisi spesifik setiap wilayah, seperti iklim dan kesuburan tanah). Oleh karena itu, setelah ketimpangan produktivitas di jawa dan luar Jawa diestimasi, tahap selanjutnya adalah menguraikan (mendekomposisi) ketimpangan tersebut ke dalam komponen terjelaskan (explained) sebagai akibat dari perbedaan karakteristik (nilai dari kovariat) dan komponen yang tidak terjelaskan (unexplained) sebagai akibat dari perbedaan koefisien regresi. Dalam melakukan ini, kami mengadopsi metode dekomposisi yang dikembangkan oleh Blinder (1973) dan Oaxaca (1973). Secara umum, dekomposisi Blinder Oaxaca merupakan metode analisis statistik yang dapat digunakan untuk menjelaskan seberapa besar perbedaan rata-rata di antara dua kelompok dapat dijelaskan oleh variabel-variabel penjelas dan perbedaan besarnya koefisien regresi (Hlavac, 2018).

Metode ini banyak digunakan untuk menganalisa pasar tenaga kerja berdasarkan kelompok (jenis kelamin, ras, dan sebagainya), yaitu dengan menguraikan perbedaan rata-rata log upah berdasarkan model regresi (Jann, 2008). Untuk kasus Indonesia, beberapa contoh penggunaan model Blinder-Oaxaca dalam konteks ini adalah Sukma dan Kadir (2018) dan Kitae, S. (2015). Namun demikian, penggunaan model ini untuk mendekomposisi gap regional (antar wilayah) juga jamak dijumpai. Pereira dan Galego (2007) menggunakan metode ini untuk mendekomposisi ketimpangan upah antar wilayah di Portugal. Sementara itu, Lima dan Cirino (2012) melakukan hal yang sama untuk Equador.

Sementara itu, aplikasi model ini di bidang pertanian umumnya digunakan untuk menganalisis ketimpangan produktivitas antara petani perempuan dan laki-laki yang terjadi di negara-negara berkembang (Mukasa dan Salami (2015); Olakojo (2017); dan Pionce (2016). Penggunaan berbeda dilakukan oleh Castany et.al (2007) yang menganalisis ketimpangan total factor productivity antara perusahaan besar dan kecil. Sepanjang pengetahuan kami, penggunaan model ini untuk menganalisis ketimpangan regional produktivitas padi sawah merupakan sesuatu yang baru, khususnya untuk konteks Indonesia.

Dekomposisi Blinder-Oacaxa dalam penelitian ini diterapkan dengan terlebih dahulu mengestimasi model regresi pada persamaan (1) secara terpisah untuk masing-masing wilayah seperti dinyatakan pada persamaan (2) untuk wilayah Jawa dan (3) untuk luar Jawa berikut

$$
\begin{aligned}
& \ln y_{i}^{J}=x_{i}^{\prime J} \beta^{J}+\varepsilon_{i}^{J} \ldots \\
& \ln y_{i}^{L J}=x_{i}^{L J} \beta^{L J}+\varepsilon_{i}^{L J}
\end{aligned}
$$

Total gap yang diestimasi dari model regresi pada persamaan (1) dengan hanya melibatkan variabel wilayah sebagai variabel penjelas didekomposisi dengan menggunakan persamaan berikut:

$$
\overline{\ln y_{l}^{J}}-\overline{\ln y_{l}^{L J}}=\left[\overline{x_{l}^{\prime J}}-\overline{x_{l}^{\prime L J}}\right] \hat{\beta}^{L J}+\overline{x_{l}^{\prime J}}\left[\hat{\beta}^{J}-\hat{\beta}^{L J}\right]
$$

Pada persamaan (4), $\left[\overline{x_{l}^{\prime J}}-\overline{x_{l}^{\prime L J}}\right]$ menjelaskan bagaimana perbedaan produktivitas antara wilayah Jawa dan luar Jawa berubah sehubungan dengan perubahan gap karakteristik antara Jawa dan luar Jawa. Analog dengan deskripsi Suh (2006), komponen ini dapat disebut sebagai "perbedaan 
produktivitas antar wilayah yang teramati dalam (perbedaan) karakteristik". Sementara itu, komponen $\left[\hat{\beta}^{J}-\hat{\beta}^{L J}\right]$ menangkap bagian tidak terjelaskan dari perbedaan produktivitas antar kedua wilayah yang terkait dengan perbedaan koefisien atau return.

\section{HASIL DAN PEMBAHASAN}

\section{Analisis deskriptif}

Secara umum, produktivitas padi nasional mengelami tren kenaikan dari tahun ke tahun. Hal ini tentu tidak terlepas dari keberhasilan program-program pemerintah yang difokuskan pada upaya memacu peningkatan produktivitas. Namun demikian, Gambar 1 menunjukkan bahwa tren kenaikan produktivitas sepanjang 2000-2018 tidak terlalu menggembirakan, bahkan cenderung melandai. Dalam kurun waktu delapan belas tahun, total kenaikan produktivitas hanya sekitar 0,5 juta ton atau sekitar 0,05 juta ton per tahun, baik di Jawa maupun di luar Jawa. Kondisi ini sebetulnya dapat diatasi dengan memacu peningkatan produktivitas di luar Jawa. Hal ini sangat memungkinkan karena kondisi budidaya tanaman padi di luar Jawa masih relatif tertinggal dari Jawa. Hal ini tercermin dari produktivitas padi di luar Jawa yang masih lebih rendah dibanding produktivitas padi di Jawa.

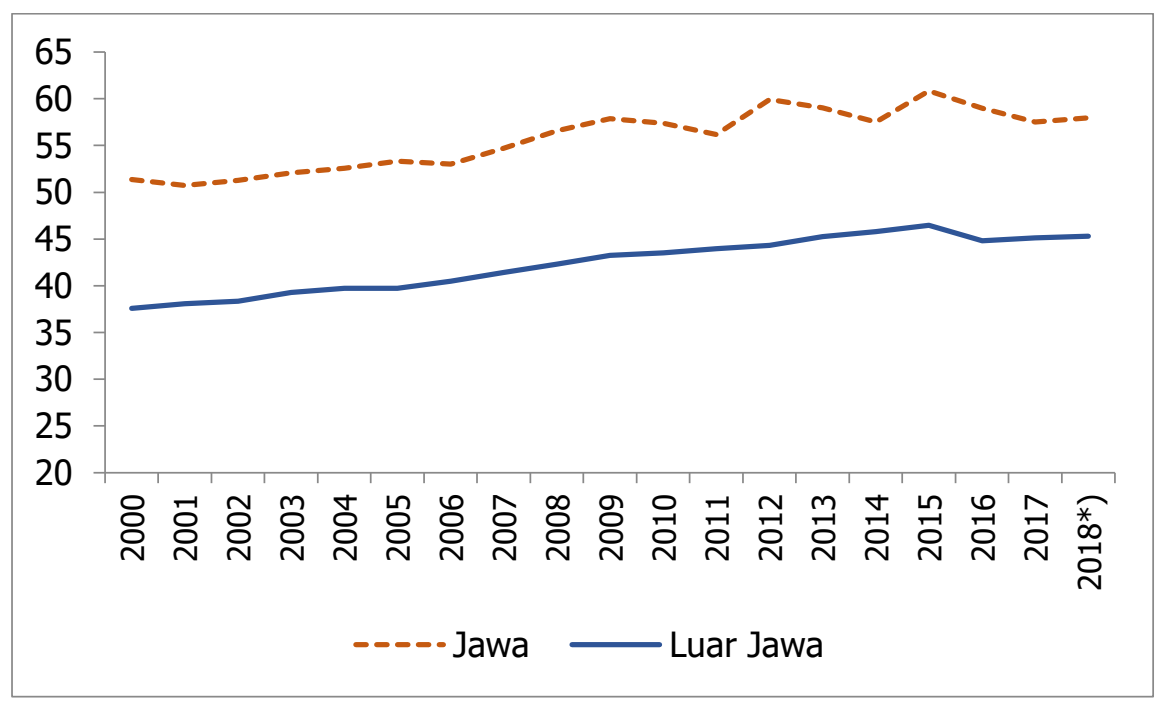

Sumber: BPS, diolah

Gambar 10. Trend Produktivitas Padi Sawah di Jawa dan Luar Jawa (kuintal per hektar), 2000-2018

Selain itu, tren kenaikan ini masih dibarengi dengan ketimpangan produktivitas secara regional, yang terjadi antara wilayah Jawa dan luar Jawa, yang cenderung persisten (Gambar 1). Kondisi ini mengakibatkan produktivitas padi secara nasional masih berkisar pada angka sekitar 6 juta ton GKG per hektar. Tabel 2 memperlihatkan bahwa produktivitas padi di luar Jawa jauh lebih rendah dibanding produktivitas padi sawah di Jawa. Terkait penggunaan pupuk, rata-rata penggunaan pupuk per plot ubinan di Jawa secara umum lebih tinggi dibanding luar Jawa, khususnya untuk penggunaan pupuk urea dan TSP/SP36. Persentase rumah tangga padi sawah di Jawa yang menggunakan pupuk juga lebih tinggi (99,46 persen) dibanding di luar Jawa (93,62 persen). Nampaknya, hal ini menjadi salah satu penyebab produktivitas padi sawah di Jawa jauh lebih tinggi dibanding di luar Jawa. Potret yang sama juga bisa dilihat pada akses terhadap irigasi. Di luar Jawa, akses rumah tangga padi sawah terhadap irigasi baru mencapai 51,93 persen, jauh lebih rendah dibanding Jawa yang telah mencapai 70,41 persen.

Tabel 2 juga memperlihatkan bahwa aplikasi pola tanam jajar legowo, yang dapat meningkatkan produktivitas padi secara signifikan (Prasetyo dan Kadir, 2019), masih sangat rendah, yakni baru mencapai sekitar 21,27 persen secara nasional di mana persentase rumah tangga padi sawah yang mengaplikasikan sistem tanam jajar legowo di luar Jawa lebih tinggi dibanding di Jawa. Hal yang sama juga terjadi pada penggunaan benih hibrida yang diharapkan dapat meningkatkan 
produktivitas padi nasional. Secara nasional, rumah tangga padi sawah yang membudidayakan padi jenis hibrida hanya sekitar 6,28 persen. Persentase rumah tangga yang menggunakan padi hibrida di luar Jawa sedikit lebih tinggi (7,85 persen) dibanding Jawa (4,48 persen). Dalam hal keanggotaan kelompok tani, sekitar 73 persen rumah tangga padi sawah di luar Jawa merupakan anggota kelompok tani. Angka ini jauh lebih tinggi dibanding keanggotaan kelompok tani di Jawa yang hanya 67,23 persen. Sejalan dengan hal ini, jangkauan bantuan pemerintah yang disalurkan melalui kelompok tani juga lebih baik di luar Jawa (27,06 persen) dibanding di Jawa (19,72 persen).

Tabel 2. Distribusi variabel penelitian

\begin{tabular}{|c|c|c|c|}
\hline Variabel & Jawa & Luar Jawa & Total \\
\hline \multicolumn{4}{|l|}{ Kontinyu (Rata-rata) } \\
\hline Produktivitas (ton GKG/ha) & 6,93 & 5,45 & 6,14 \\
\hline $\begin{array}{l}\text { Penggunaan pupuk urea } \\
\text { (kg/plot ubinan) }\end{array}$ & 66,33 & 59,26 & 62,55 \\
\hline $\begin{array}{l}\text { Penggunaan pupuk TSP/SP36 } \\
\text { (kg/plot ubinan) }\end{array}$ & 27,52 & 19,94 & 23,46 \\
\hline $\begin{array}{l}\text { Penggunaan pupuk KCL (kg/plot } \\
\text { ubinan) }\end{array}$ & 5,35 & 5,80 & 5,59 \\
\hline $\begin{array}{l}\text { Penggunaan pupuk NPK } \\
\text { (kg/plot ubinan) }\end{array}$ & 38,49 & 41,20 & 39,94 \\
\hline $\begin{array}{l}\text { Penggunaan pupuk } \\
\text { kompos/organik padat (kg/plot } \\
\text { ubinan) }\end{array}$ & 38,38 & 7,31 & 21,76 \\
\hline $\begin{array}{l}\text { Penggunaan pupuk organik cair } \\
\text { (kg) }\end{array}$ & 0,70 & 0,49 & 0,59 \\
\hline \multicolumn{4}{|l|}{ Dummy (\%) } \\
\hline Irigasi & 70,41 & 51,93 & 60,52 \\
\hline Non-irigasi & 29,59 & 48,07 & 39,48 \\
\hline Monokultur & 98,76 & 97,81 & 98,25 \\
\hline Mixcrop & 1,24 & 2,19 & 1,75 \\
\hline Menqqunakan pupuk & 99,46 & 93,62 & 96,33 \\
\hline Tidak menggunakan pupuk & 0,54 & 6,38 & 3,67 \\
\hline Hibrida & 4,48 & 7,85 & 6,28 \\
\hline Non-hibrida & 95,52 & 92,15 & 93,72 \\
\hline Mengqunakan pestisida & 77,72 & 77,71 & 77,72 \\
\hline Tidak menggunakan pestisida & 22,28 & 22,29 & 22,28 \\
\hline Jarwo 2:1 & 3,5 & 4,0 & 3,77 \\
\hline Jarwo 4:1 & 5,68 & 9,14 & 7,53 \\
\hline Jarwo 6:1 & 4,05 & 5,58 & 4,87 \\
\hline Jarwo lainnya & 4,09 & 5,98 & 5,10 \\
\hline Non-jarwo & 82,68 & 75,30 & 78,73 \\
\hline Bantuan & 19,72 & 27,06 & 23,65 \\
\hline Non-bantuan & 80,28 & 72,94 & 76,35 \\
\hline Anggota poktan & 67,23 & 73,00 & 70,31 \\
\hline Bukan angqota poktan & 32,77 & 27,00 & 29,69 \\
\hline Jumlah observasi & 29.331 & 33.740 & 63.071 \\
\hline
\end{tabular}

Catatan: Angka resmi penghitungan produktivitas dihitung dengan cara yang berbeda dengan yang digunakan dalam paper ini

\section{Ketimpangan Produktivitas di Jawa dan Luar Jawa}

Hasil estimasi model regresi pada persamaan (1) yang disajikan pada Tabel 2 memperlihatkan bahwa tanpa mengontrol variabel lain yang mempengaruhi produktivitas selain wilayah, rata-rata produktivitas tanaman padi sawah di luar Jawa lebih rendah sekitar 28 persen dibanding produktivitas padi sawah di Jawa. Hal ini sejalan dengan plot kernel density dari distribusi nilai produktivitas tanaman padi sawah di masing-masing wilayah yang tersaji pada Gambar 2. Gambar 2 memperlihatkan bahwa gap produktivitas antar kedua wilayah dapat dipersempit dengan 
menggeser distribusi produktivitas padi di luar Jawa ke sisi kanan. Jika variabel-variabel lain yang juga mempengaruhi produktivitas diikutkan ke dalam model regresi, gap produktivitas hanya mengalami penurunan yang relatif kecil menjadi sekitar 24 persen. Hal ini mengindikasikan bahwa porsi total gap yang bisa dijelaskan oleh semua karakteristik pada Tabel 3 relatif kecil. Dengan kata lain, sebagian besar ketimpangan produktivitas antar wilayah Jawa dan luar Jawa tidak terjelaskan.

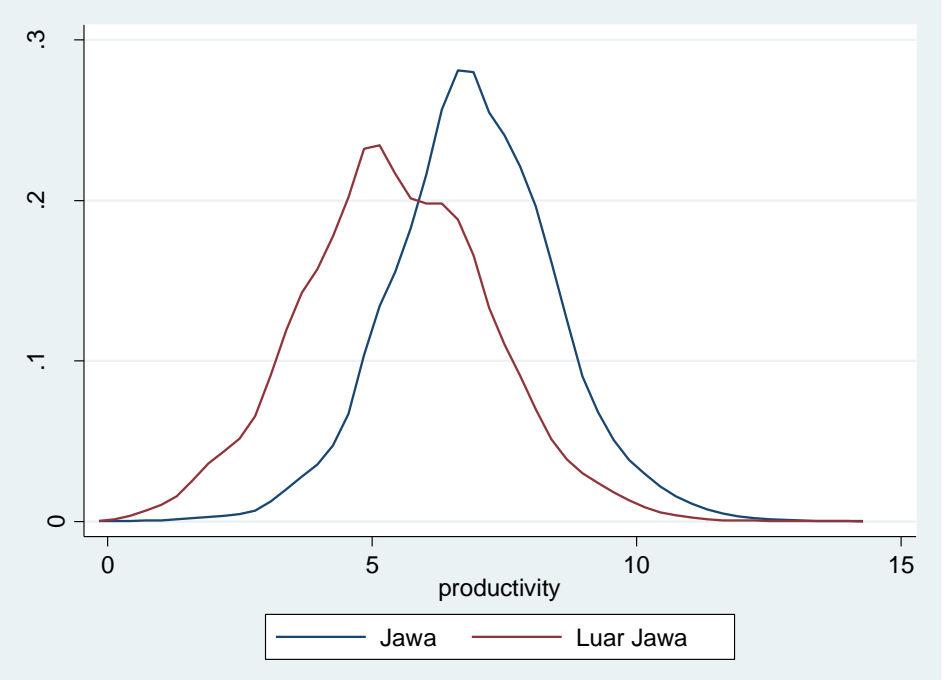

Gambar 2. Kernel density produktivitas padi sawah di Jawa dan Luar Jawa ( banwidth $=0.25$ )

Hasil estimasi model regresi juga memperlihatkan bahwa sebagian besar variabel yang diikutsertakan ke dalam model regresi signifikan secara statistik pada level signifikansi 5 persen dalam menjelaskan variasi produktivitas. Akses terhadap irigasi dapat meningkatkan produktivitas padi sekitar 12 persen. Sementara itu, penggunaan benih hibrida belum signifikan dalam meningkatkan produktivitas padi secara nasional. Hal ini dapat dijelaskan oleh proporsi rumah tangga padi sawah yang membudidayakan padi jenis ini yang masih di bawah 10 persen. Penggunaan pupuk memiliki magnitude yang paling besar dan signfikan dalam meningkatkan produktivitas tanaman padi sawah, yakni sekitar 37 persen. Terkait hal ini, Tabel 4 menunjukkan bahwa magnitude penggunaan pupuk yang relatif besar ini lebih merupakan fonomena di luar Jawa ketimbang di Jawa karena proporsi rumah tangga padi sawah yang belum menggunakan pupuk masih relatif besar (6,38 persen). Penggunaan pupuk di luar Jawa dapat meningkatkan produktivitas sekitar 39 persen sementara di Jawa dampaknya tidak signifikan secara statistik karena hampir seluruh petani padi sawah sudah menggunakan pupuk (99 persen).

Seperti yang diharapkan, penerapan pola tanam jajar legowo signifikan secara statistik dalam meningkatkan produktivitas padi sawah sekitar 7 persen. Tabel 4 memperlihatkan bahwa dampak positif penerapan pola tanam jajar legowo konsisten baik di Jawa maupun di luar Jawa. Sejalan dengan hal ini, bantuan pemerintah dan keanggotaan kelompok tani juga berpengaruh postif dan signifikan dalam meningkatkan produktivitas budidaya tanaman padi sawah. Dampak positif ini juga konsisten baik di Jawa maupun luar Jawa. Sementara itu, penggunaan pestisida dalam pengendalian serangan hama dan organisme penggangu tumbuhan (OPT) tidak terlalu efektif dalam meningkatkan produktivitas. Hal ini memperlihatkan bahwa cara pengendalian OPT lainnya, seperti agronomis, mekanis, dan hayati lebih efektif dalam meningkatkan produktivitas tanaman padi sawah. Tabel (3) dan (4) juga mengkonfirmasi bahwa nilai produktivitas juga bervariasi antar subround di mana subround satu cenderung lebih tinggi dibanding subround dua dan tiga. 
Tabel 3. Hasil estimasi OLS persamaan (1): sampel gabungan

\begin{tabular}{lcc}
\hline \multicolumn{1}{c}{$\begin{array}{c}\text { Variabel independen: } \\
\text { log(produktivitas) }\end{array}$} & $\mathbf{( 1 )}$ & $\mathbf{( 2 )}$ \\
\hline Luar Jawa & $-0,2770(0,0085)^{* * *}$ & $-0,2421(0,0073)^{* * *}$ \\
Irigasi & - & $0,1201(0,0066)^{* * *}$ \\
Monokultur & - & $0,0352(0,0277)$ \\
Hibrida & - & $-0,0221(0,0185)$ \\
Pupuk & - & $0,3685(0,0194)^{* * *}$ \\
Pestisida & - & $-0,0176(0,0075)^{* *}$ \\
Jarwo 2:1 & - & $0,0659(0,0130)^{* * *}$ \\
Jarwo 4:1 & - & $0,0776(0,0145)^{* * *}$ \\
Jarwo 6:1 & - & $0,0703(0,0121)^{* * *}$ \\
Jarwo lainnya & - & $0,0510(0,1118)^{* * *}$ \\
Bantuan & - & $0,0168(0,0062)^{* * *}$ \\
Poktan & - & $0,0494(0,0045)^{* * *}$ \\
Subround II & - & $-0,0876(0,0062)^{* * *}$ \\
Subround III & - & $-0,0146(0,0099)$ \\
Konstanta & $1,9076(0,0036)^{* * *}$ & $1,4283(0,0249)^{* * *}$ \\
Adjusted-R & 0,1469 & 0,2441 \\
Jumlah Observasi & 63.071 & 63.071
\end{tabular}

Catatan: robust standard error ada di dalam kurung; *** signifikan pada tingkat signifikansi 1 persen; ** signifikan pada tingkat signifikansi 5 persen; * signifikan pada tingkat signifikansi 10 persen.

Tabel 4. Hasil estimasi persamaan (2) dan (3): menurut wilayah

\begin{tabular}{|c|c|c|}
\hline $\begin{array}{l}\text { Variabel independen: } \\
\text { log(produktivitas) }\end{array}$ & Luar Jawa & Jawa \\
\hline Irigasi & $0,1684(0,0107)^{* * *}$ & $0,0509(0,0077)^{* * *}$ \\
\hline Monokultur & $0,0448(0,0428)$ & $0,0048(0,0122)$ \\
\hline Hibrida & $-0,0316(0,0268)$ & $-0,0048(0,0111)$ \\
\hline Pupuk & $0,3919(0,0100)^{* * *}$ & $-0,0579(0,0330)^{*}$ \\
\hline Pestisida & $-0,0241(0,0120)^{* *}$ & $-0,0072(0,0065)$ \\
\hline Jarwo 2:1 & $0,0568(0,0219)^{* *}$ & $0,0817(0,0116)^{* * *}$ \\
\hline Jarwo 4:1 & $0,0859(0,0232)^{* * *}$ & $0,0577(0,0132)^{* * *}$ \\
\hline Jarwo 6:1 & $0,0714(0,0171)^{* * *}$ & $0,0709(0,0121)^{* * *}$ \\
\hline Jarwo lainnya & $0,0632(0,0163)^{* * *}$ & $0,0327(0,0157)^{* *}$ \\
\hline Bantuan & $0,0149(0,0093)$ & $0,0198(0,0078)^{* *}$ \\
\hline Poktan & $0,0266(0,0081)^{* * *}$ & $0,0757(0,0060)^{* * *}$ \\
\hline Subround II & $-0,1030(0,0114)^{* * *}$ & $-0,0701(0,0055) * * *$ \\
\hline Subround III & $-0,0135(0,0173)$ & $-0,0066(0,068)$ \\
\hline Konstanta & $1,1577(0,0290) * * *$ & $1,8965(0,0358)^{* * *}$ \\
\hline Adjusted-R ${ }^{2}$ & 0,1524 & 0,0600 \\
\hline Jumlah Observasi & 33.740 & 29.331 \\
\hline
\end{tabular}

Catatan: robust standard error ada di dalam kurung; *** signifikan pada tingkat signifikansi 1 persen; ** signifikan pada tingkat signifikansi 5 persen; * signifikan pada tingkat signifikansi 10 persen. 
Tabel 5. Hasil dekomposisi Blinder-Oaxaca

\begin{tabular}{|c|c|c|}
\hline $\begin{array}{l}\text { Total gap: } 0,2770 \\
(0,0075) * * *\end{array}$ & $\begin{array}{l}\text { Total explained gap: } 0,0464 \\
(0,0037)^{* * *}\end{array}$ & $\begin{array}{l}\text { Total unexplained gap: } \\
0,2306(0,0076) * * * \\
\end{array}$ \\
\hline Irigasi & $0,0311(0,0032)^{* * *}$ & $-0,0827(0,0098)^{* * *}$ \\
\hline Monokultur & $0,0004(0,0004)$ & $-0,0395(0,0465)$ \\
\hline Hibrida & $0,0011(0,0009)$ & $0,0012(0,0012)$ \\
\hline Pupuk & $0,0229(0,0024)^{* * *}$ & $-0,4474(0,0441)^{* * *}$ \\
\hline Pestisida & $-0,000001(0,0003)$ & $-0,0131(0,0109)$ \\
\hline Jarwo 2:1 & $-0,0003(0,0003)$ & $0,0009(0,0009)$ \\
\hline Jarwo 4:1 & $-0,0030(0,0010)^{* * *}$ & $-0,0016(0,0016)$ \\
\hline Jarwo 6:1 & $-0,0011(0,0004)^{* * *}$ & $-0,00003(0,0008)$ \\
\hline Jarwo lainnya & $-0,0012(0,0004)^{* * *}$ & $-0,0013(0,0010)$ \\
\hline Bantuan & $-0,0011(0,0007)$ & $0,0010(0,0026)$ \\
\hline Poktan & $-0,0015(0,0006)^{* * *}$ & $0,0330(0,0074)^{* * *}$ \\
\hline Subround II & $-0,0013(0,0012)$ & $0,0141(0,0057)^{* *}$ \\
\hline Subround III & $0,0003(0,0004)$ & $0,0011(0,0032)$ \\
\hline Konstanta & - & $0,7388(0,0386)^{* * *}$ \\
\hline
\end{tabular}

Hasil dekomposisi dengan metode Blinder-Oaxaca yang disajikan pada Tabel 5 memperlihatkan bahwa hanya sekitar 16 persen dari total gap yang dapat dijelaskan oleh perbedaan karakteristik (variabel indpenden pada model regresi). Sekitar 84 persen sisanya tidak terjelaskan dan ditangkap oleh perbedaan koefisien regresi. Hal ini menunjukkan bahwa masih banyak variabel yang dapat menjelaskan gap produktivitas yang tidak disertakan ke dalam spesifikasi model. Variabel-variabel tersebut antara lain adalah kapasitas petani (karakteristik demografi dan modal manusia), kondisi iklim, infrastruktur dan mekanisasi pertanian, tingkat kesuburan tanah, dan lain-lain.

Hasil dekomposisi juga memperlihatkan bahwa kesenjangan produktivitas antara wilayah Jawa dan luar Jawa dapat dipersempit dengan meningkatkan akses petani padi sawah terhadap irigasi dan penggunaan pupuk di luar Jawa. Selain itu, penerapan pola tanam jajar legowo yang lebih masif di luar Jawa serta penguatan peran kelompok tani dalam memanfaatkan bantuan pemerintah juga dapat mempersempit gap produktivitas yang ada.

\section{KESIMPULAN}

Ketimpangan produktivitas padi sawah yang terjadi antara Jawa dan luar Jawa masih cukup signifikan, yakni sekitar 28 persen. Hal ini mengindikasikan bahwa masih ada peluang untuk meningkatkan produktivitas padi di luar Jawa untuk paling tidak mendekati nilai produktivitas di Jawa. Hasil dekomposisi menunjukkan bahwa hanya sekitar 16 persen dari total gap produktivitas antara kedua wilayah yang dapat dijelaskan oleh perbedaan karakteristik, seperti akses terhadap irigasi, penggunaan pupuk, penerapan teknik budidaya jajar legowo, dan partisipasi dalam keanggotaan kelompok tani. Hal ini menunjukkan bahwa masih banyak variabel yang dapat menjelaskan gap produktivitas yang tidak disertakan ke dalam spesifikasi model. Variabel-variabel tersebut antara lain adalah kapasitas petani (karakteristik demografi dan modal manusia), kondisi iklim, infrastruktur dan mekanisasi pertanian, tingkat kesuburan tanah, dan lain-lain. Karena itu, diperlukan penelitian lebih lanjut yang mengikutsertakan variabel-variabel tersebut ke dalam model. Hasil dekomposisi juga memperlihatkan bahwa ketimpangan produktivitas antar kedua wilayah dapat dipersempit dengan meningkatkan akses terhadap irigasi, peningkatan penggunaan pupuk, peningkatan sistem penanaman Jajar Legowo serta peningkatan keanggotaan dalam kelompok tani sebagai upaya peningkatan produksi padi di luar Jawa dan di luar Jawa. 


\section{DAFTAR PUSTAKA}

Blinder, A. S. (1973). Wage discrimination: Reduced form and structural estimates. Journal of Human Resources,8,436-455.

BPS. (2018). Kajian Konsumsi Bahan Pokok tahun 2017. Badan Pusat Statistik.

BPS. (2018). Pedoman Pengumpulan Data Survei Ubinan Tanaman Pangan 2018. Badan Pusat Statistik.

BPS. (2019). Buletin Statistik Perdagangan Luar Negeri Impor. BPS RI.

Castany, L., Bazo, E.L., \& Moreno, R. (2007). Decomposing Differences In Total Factor Productivity Across Firm Size. Working papersResearch Institute of Applied Economics 2007/5.

Cirino, J.F. \& Lima J.E. (2012). Wage Differentials between the Metropolitan Regions of Belo Horizonte and Salvador: a Discussion Based on the Blinder-Oaxaca Decomposition. Technical-Scientific Document 43(2).

Hill, R. Charter, Griffiths, William E, dan Lim, Guay C. (2011). Pronciples of Econometrics Fourth Edition. John Wiley \& Sons.

Hlavac, Marek (2018). oaxaca: Blinder-Oaxaca Decomposition in R. $R$ package version 0.1.4. https://CRAN.Rproject.org/package $=$ oaxaca.

Indonesia Investment. (2017). Rice. investments.com/business/commodities/rice/ item183.

Jann, B. (2008). The Blinder-Oaxaca Decomposition for Linear Regression Models. The Stata Journal 8 (4): $453-479$.

Kitae,S. (2015). Gender discrimination in earnings in Indonesia: $A$ fuller picture. Bulletin of Indonesian Economic Studies,51(1),95-121.

Nichols, Austin \& Schaffer, Mark. (2007). Clustered standard errors in STATA. Cited in https://www.researchgate.net/publication/4923121 Clustered standard errors in STATA

Oaxaca, R. (1973). Male-female wage differentials in urban labour markets. International Economic Review, 14,693-709.

Olakojo, Solomon. (2017). Gender Gap In Agricultural Productivity In Nigeria: A Commodity Level Analysis. Economics of Agriculture 2/2017.

Pereira, J. \& Galego, A. (2007). Regional Wage Differentials: Static and Dynamic Approaches. CEFAGE-UE Working Paper.

Pionce, Elizabeth G.G. (2016). Agricultural Performance In Northern Ghana: A Gender Decomposition. Master Thesis. Kansas State University.

Prasetyo, O. R. \& Kadir, K. (2019). Teknik Penanaman Jajar Legowo Untuk Peningkatan Produktivitas Padi Sawah di Jawa Tengah. Jurnal Litbang Sukowati : Media Penelitian dan Pengembangan. 3. 13. 10.32630/sukowati.v3i1.88.

Salami, O.A., Mukasa, N.A. (2015). Gender productivity differentials among smallholder farmers in Africa: A cross-country comparison. Working paper series No. 213. African Development Bank.

Suh, J. (2006). Decomposition of the change in the gender wage gap. Research in Business and Economics Journal, 1(1).

Sukma, W.L \& Kadir. (2019). Decomposition of the Gender Wage Gap in Indonesia: Analysis from Sakernas Data. MPRA Paper 94930, University Library of Munich, Germany. https://ideas.repec.org/p/pra/mprapa/94930.html. 